\title{
Advanced Oil Recovery Technologies for Improved Recovery From Slope Basin Clastic Reservoirs, Nash Draw Brushy Canyon Pool, Eddy County, New Mexico
}

\author{
Quarterly Report \\ April 1 - June 30, 1997
}

\author{
By \\ Mark B. Murphy
}

Work Performed Under Contract No.: DE-FC22-95BC14941

For

U.S. Department of Energy

Office of Fossil Energy

Federal Energy Technology Center

P.O. Box 880

Morgantown, West Virginia 26507-0880

By

Strata Production Company

P. O. Box 1030

Roswell, New Mexico 88202 


\section{Disclaimer}

This report was prepared as an account of work sponsored by an agency of the United States Government. Neither the United States Government nor any agency thereof, nor any of their employees, makes any warranty, express or implied, or assumes any legal liability or responsibility for the accuracy, completeness, or usefulness of any information, apparatus, product, or process disclosed, or represents that its use would not infringe privately owned rights. Reference herein to any specific commercial product, process, or service by trade

name, trademark, manufacturer, or otherwise does not necessarily constitute or imply its endorsement, recommendation, or favoring by the United States Government or any agency thereof. The views and opinions of authors expressed herein do not necessarily state or reflect those of the United States Government or any agency thereof. 


\title{
QUARTERLY TECHNICAL PROGRESS REPORT
}

(Seventh Quarter)

\section{ADVANCED OIL RECOVERY TECHNOLOGIES FOR IMPROVED RECOVERY FROM SLOPE BASIN CLASTIC RESERVOIRS, NASH DRAW BRUSHY CANYON POOL, EDDY COUNTY, NM}

DOE Cooperative Agreement No. DE-FC-95BC14941

\author{
Strata Production Company \\ P.O. Box 1030 \\ Roswell, NM 88202 \\ (505) 622-1127
}

Date of Report:

Award Date:

Anticipated Completion Date:

Award Amount for Current Fiscal Year:

Award Amount for Budget Period I:

Name of Project Manager:

Contracting Officer's

Representative:

Reporting Period:
July 30, 1997

September 25, 1995

September 24, 1997 - Budget Period I

September 25, 2000 - Budget Period II

$\$ 2,011,213$

$\$ 3,354,067$

Mark B. Murphy

Mary Beth Pearse

April 1, 1997 - June 30, 1997

US/DOE Patent Clearance is not required prior to the publication of this document. 


\section{DISCLAIMER}

This report was prepared as an account of work sponsored by an agency of the United States Government. Neither the United States Government nor any agency thereof, nor any of their employees, makes any warranty, express or implied, or assumes any legal liability or responsibility for the accuracy, completeness, or usefulness of any information, apparatus, product, or process disclosed, or represents that its use would not infringe privately owned rights. Reference herein to any specific commercial product, process, or service by trade name, trademark, manufacturer, or otherwise does not necessarily constitute or imply its endorsement, recommendation, or favoring by the United States Government or any agency thereof. The views and opinions of authors expressed herein do not necessarily state or reflect those of the United States Government or any agency thereof.

\section{OBJECTIVE}

The overall objective of this project is to demonstrate that a development program - based on advanced reservoir management methods - can significantly improve oil recovery. The plan includes developing a control area using standard reservoir management techniques and comparing its performance to an area developed using advanced reservoir management methods. Specific goals are (1) to demonstrate that an advanced development drilling and pressure maintenance program can significantly improve oil recovery compared to existing technology applications and (2) to transfer these advanced methodologies to oil and gas producers in the Permian Basin and elsewhere throughout the U.S. oil and gas industry.

\section{SUMMARY OF TECHNICAL PROGRESS}

This is the seventh quarterly progress report on the project. Results obtained to date are summarized.

\section{MANAGEMENT AND PROJECT PLANNING}

Geological, engineering, geophysical, and simulation teams continue compiling and analyzing data. Data has been entered into a geological model, and initial reservoir simulation runs have been performed. The 3-D seismic data has been interpreted, and areas have been identified for targeted drilling. The first well based on the seismic data was drilled in March 1997. 
Communication and coordination between the team members located in diverse geographic areas requires the use of state-of-the-art communication systems. Therefore, to meet our reporting requirements, we use a combination of E-mail, the Internet, and high capacity data transfer to successfully exchange data and conclusions among the groups.

\section{$\underline{\text { Geology }}$}

In order to benefit from the reservoir characterization, 3-D seismic and reservoir simulation information, the geology of the Nash Draw Pool (NDP) should fit into an accepted geological model. Once the project is set within the confines of the model, the data gleaned from this project may then be applied to other fields in a similar geological setting in this and other basins.

We have established that each of the reservoirs in the study is actually a series of stacked micro-reservoirs forming an amalgamated composite reservoir. The " $L$ " sand appears to have a "primary" depositional area and a fringing "secondary" depositional area as exhibited by the seismic results. The secondary depositional composites are more disjointed and isolated, forming an apron in front of the primary area. While the original subsurface mapping interpretations suggested a stricter, more linear channel morphology, the geological model derived from the 3-D seismic data volume suggests a less linear morphology. The reservoir sand distribution, as a function of the composite porosity of the thin-bed turbidite reservoirs, has a lobate morphology that trends in a north - south direction. This morphology is clearly seen in "L" sand reflection amplitude plot. The NDP is within the mid- to distal portion of the lobe.

The sands are part of a lowstand systems tract. They are probably of eolian origin and were transported basin-ward through shelf by-pass systems. They may fit into what would be a mid-slope turbidite sequence of shingled turbidites, part of a prograding complex in Vail's scheme. Shingled turbidites are comprised of amalgamated sands that appear to be continuous. The sands seem to fit the seismic criteria as well. The internal seismic architecture is discontinuous and chaotic, within localized sequence boundaries. The seismic expression is an overall tabular unit with subparallel to basinal thinning reflections.

The unit extends across the 3-D volume indicating a widespread sheet of amalgamated turbidites. From $\log$ to $\log$, the "L" sand appears to be continuous throughout the unit as well. This is a preliminary interpretation of a geological model for the NDP.

Further study of the NDP Well \#23 core and case studies in the literature will be undertaken to more clearly define the geologic model that best fits the basal Brushy Canyon sands in the NDP. High resolution sequence stratigraphic analysis from the well logs will be incorporated and integrated with the seismic data as well. 


\section{Engineering}

The NDP Well \#29 was drilled as a data well to confirm a seismic anomaly by targeted drilling. The well resulted in an "L" Zone with $5.2 \mathrm{~m}$ (16.0 feet) of net pay (NP) with a weighted average porosity of $12.5 \%$, for a total of 0.66 Porosity-Meters (2.0 PorosityFeet (PF). The expected values from the seismic amplitude calculations indicated a well with 0.95 Porosity-Meters (2.9 PF) and 7.3 meters NP (22.4 ft NP). The predicted values varied by approximately $40 \%$ from the actual values seen in the well. Further investigation revealed the location of the well was approximately two to three bins northeast of the area of maximum amplitude. Negative amplitudes associated with the bin where the NDP Well \#29 was drilled has a value of -20 and the maximum amplitude associated with the sand pod is -30 to -35 .

Completion of the NDP Well \#29 began in May 1997. Log analysis indicated the "L" zone contained most of the oil productive zones in the Brushy Canyon interval. Therefore, only the "L" zone was selectively perforated from $2,080 \mathrm{~m}$ to $2,094 \mathrm{~m}(6,825 \mathrm{ft}$ to $6,870 \mathrm{ft})$ with twenty-three (23) 1.07-cm (0.42") diameter perforations. The perforations were acidized with $71 / 2 \%$ NEFE hydrochloric acid with fifty (50) rubber coated nylon ball sealers. The perforations were "balled out" to ensure all perforations were open and taking fluid. Results after the acid treatment indicated good fluid entry with a 30\% oil cut and a good show of gas.

To facilitate the design of the fracturing treatment, a Digital Array Sonic Log was run, and a Frac Log with mechanical rock properties was derived. Rock properties included Young's Modulus, Poisson's Ratio, and frac gradient. A frac pressure was calculated for each half-foot interval and plotted against depth, as shown in Figure 1. Barriers were indicated at the shale-lime sequence on top of the Bone Spring at 2,100 $\mathrm{m}(6,890 \mathrm{ft})$ and in the upper "K" zone at 2,054 $\mathrm{m}$ or $2,039 \mathrm{~m}(6,740 \mathrm{ft}$ or $6,690 \mathrm{ft})$. This indicated a gross frac height of $43 \mathrm{~m}$ to $61 \mathrm{~m}$ (140 feet to 200 feet).

The fracture stimulation treatment was designed for $66 \mathrm{~m}$ (216.5 feet) of height and $110 \mathrm{~m}$ (360.5 feet) of propped fracture half-length. If the height was only $43 \mathrm{~m}$ (140 feet), the length would be approximately $122 \mathrm{~m}$ (400 feet). The zone was fractured with $246 \mathrm{~m}^{3}$ (65,000 gallons) of $4.2 \mathrm{~kg} / \mathrm{m}^{3}$ (35 lb./1000 gals.) crosslinked gelled water carrying 98,376 $\mathrm{kg}(216,880 \mathrm{lbs}) 16 / 30 \mathrm{sand}$ at an average rate of $0.055 \mathrm{~m}^{3} / \mathrm{s}(21 \mathrm{BPM})$.

A temperature log was run at three, four, and six hours after the fracturing treatment to determine fluid entry. The temperature $\log$ indicated the majority of the fracturing treatment was contained from $2,056 \mathrm{~m}$ to $2,096 \mathrm{~m}(6,745 \mathrm{ft}$ to $6,875 \mathrm{ft})$. There is an indication of greater cooling and that larger volumes of fluid entered from 2,057 $\mathrm{m}$ to 2,076 $\mathrm{m}(6750 \mathrm{ft}$ to $6810 \mathrm{ft})$ and $2,086 \mathrm{~m}$ to $2,091(6,845 \mathrm{ft}$ to $6,860 \mathrm{ft})$. The temperature $\log$ confirmed that the lower "K", "K-2"and "L" zones were stimulated by the fracturing treatment.

Log analysis of this interval, with core-calibrated calculations using "L" zone porosity-permeability relationships for the oil productive zones and "K-2" zone porosity- 
permeability relationships for the water productive zones, indicates the well should produce $26.7 \mathrm{~m}^{3} /$ day oil (168 BOPD) and $189 \mathrm{~m}^{3} /$ day water (1,187 BWPD). After cleanup and stabilization the well averaged $11.9 \mathrm{~m}^{3} /$ day (74.8 BOPD) and $86.8 \mathrm{~m}^{3} /$ day (546 BWPD) from June 14th through June 19th. A fluid level obtained on June 24th indicated a fluid level at $771 \mathrm{~m}(2,529 \mathrm{ft})$ from the surface, which indicates there is $1,311 \mathrm{~m}$ (4,300 feet) of gas-cut fluid above the perforations. This high fluid level indicates that higher production rates are possible if sufficient lift equipment were available to produce the available fluid. The actual oil cut of $13.7 \%$ is close to the predicted oil cut of $14.2 \%$.

A size 912 pumping unit installation is being designed to move in excess of 95.4 $\mathrm{m}^{3} /$ day (600 barrels of fluid per day). The installation of this larger unit will occur during the first part of August 1997. Reduction of the fluid level and additional testing will be required to fully evaluate this well.

The application of the Core-Calibrated Advanced Log Analysis Tool (ALA) to two other Delaware wells in southeast New Mexico was performed with good results. The first application was a standard analysis similar to the NDP. The second application in a new rock type required a major correction in log values (14\%) to accurately predict pay intervals. The wells have been completed, and one well agreed closely with predictions while the other well has higher water cuts than predicted. The higher water cuts are believed to be the result of down-dip water and possible scaling in the oil productive zones. A remedial treatment is being planned for this well.

A directional/horizontal well is being designed to drill a seismic amplitude anomaly under a playa lake in the western part of Section 12. Due to the close proximity to the playa lake, the BLM has requested the surface location be moved to $455 \mathrm{~m}$ (1,460 ft) FSL and 483 $\mathrm{m}(1,585 \mathrm{ft}) \mathrm{FWL}$ of Section 12.The revised plan is to deviate the well $283 \mathrm{~m}(930 \mathrm{ft})$ and then drill a $341 \mathrm{~m}(1,120 \mathrm{ft})$ horizontal section through the "L" zone. The bottomhole location will be $625 \mathrm{~m}(2,050 \mathrm{ft})$ west-northwest of the surface location at $455 \mathrm{~m}(1,460 \mathrm{ft})$ FSL and $483 \mathrm{~m}(1,585 \mathrm{ft}) \mathrm{FWL}$ of Section 12, T23S-R29E. This will be the first well to test targeted deviated/horizontal drilling to develop reserves under the playa lakes and under the potash area. The well schematic is presented in Figure 2.

Preliminary cost estimates indicate the drilling cost will increase by approximately $\$ 165,000$ and completion cost will increase by $\$ 115,000$. The total cost of a directionalhorizontal well is estimated to be $\$ 874,000$. Economic and feasibility studies will continue to determine the viability of directional-horizontal drilling at the NDP.

\section{$\underline{\text { Reservoir Characterization/Reservoir Simulation }}$}

Activities of the Reservoir Characterization/Simulation Team for the second quarter of 1997 were focused on: (1) the re-validation of a simulation model for the proposed pilot area centered around NDP Well \#1 to account for an additional six months of production history 
and to reflect a higher (16.7\%) recovery factor, and (2) an investigation of the probable impact of the early implementation of pressure maintenance options on oil recovery.

As discussed in the last quarterly report, our criteria for a "good" match of historical performance are reasonable agreements between simulated values and actual values of the following:

- drainage area average pressure for each well (as opposed to BHP)

- oil production by well

- water production by well

- gas production by well

Oil production by well was used as the driving function for the simulations. Consequently, it would be expected that oil rates would be honored exactly by the simulations. However, all five of the Nash Draw wells in the pilot area reach pumping conditions during the validation step. When a simulated well reaches pumping conditions, the oil rate is not necessarily honored by the simulator, and the oil rate itself becomes a history matching parameter. In this case the bottomhole pressure becomes the driving function.

Simulated pressure responses for the five pilot wells during the period ending on March 1, 1997 are plotted in Figure 3. These represent the best results obtained to date. They reflect drainage area volumes that are within $10 \%$ of the original oil volumes which correspond to the $16.7 \%$ recovery case. The oil rates for each of the wells in the pilot area are displayed in Figure 4. As the bottomhole pressure declines to pumping conditions, simulated well production deviates slightly from field measured values. Figure 5 exhibits the simulated and observed gas production rates. Adjustments were made to the gas-oil relative permeability data for this case. No actual gas-oil relative permeability measurements from the laboratory were available.

Although results are still preliminary, it appears that early conversion of NDP Well \#1 from a producer to a gas injector, would double the oil recovery during the first few years of production from the entire five-spot pattern. For example, if NDP Well \#1 was converted to gas injection after the first year of production, the average pressure in the entire "lobe" would not decline below $10,342.14 \mathrm{kPa}(1500 \mathrm{psi})$, and the producing GOR would remain below $0.43 \mathrm{mscf} / \mathrm{STB}$ through March, 1997. The oil rates for the remaining producers would have been in the range of $7.95 \mathrm{~m}^{3} /$ day $(50 \mathrm{STB} / \mathrm{d})$ for at least a year after the onset of gas injection. The principal implication of this result is that pressure maintenance should start very early after the onset of production in any new pattern in the NDP.

\section{TECHNOLOGY TRANSFER}

Transferring technical information generated during the course of this project is a prime objective of the project. Toward this objective, Strata has participated in several 
meetings and workshops to promote the dissemination of information generated during this quarter. A summary of these activities is outlined.

Informal DOE Meeting - In April 1997, several members of the Nash Draw team discussed results obtained in the NDP project with BPO field office personnel during a half-day meeting in Bartlesville, Oklahoma.

DOE Oil Technology Project Review - In June 1997, results obtained in the NDP Class III project were presented at the DOE Oil Technology Project Review Meeting in Houston, Texas.

SPE Paper Accepted - A paper titled "Reservoir Characterization as a Risk Reduction Tool at the Nash Draw Pool", will be presented at the SPE Annual Technical Conference and Exhibition to be held in San Antonio, Texas in October, 1997.

IEA Paper Accepted - A paper entitled "Optimizing Oil Recovery from a Complex, Low Permeability Turbidite Reservoir" is being prepared for presentation at the $199718^{\text {th }}$ International Energy Agency Workshop and Symposium on Enhanced Oil Recovery to be held in Copenhagen, Denmark in September, 1997.

Geophysics Papers Submitted - Two papers have been submitted to Geophysics for peer review and publication. The paper titles are "3-D Seismic Imaging and Interpretation of Brushy Canyon Thin-Bed Turbidite Reservoirs, Northwest Delaware Basin" and "3-D Seismic Imaging of Reservoir Compartment Boundaries Across an Area of Complex Turbidite Deposition".

Workshop - BDM Oklahoma and the Department of Energy will hold a workshop titled "Advanced Applications of Wireline Logging for Improved Recovery" in September 1997. Strata's project has been invited to be a participant in the workshop.

Workshop - A workshop is planned for September in conjunction with a reservoir characterization symposium coordinated by the PRRC at New Mexico Tech. The program will be given in Hobbs, New Mexico. This will fulfill a portion of the technology transfer requirements for the Nash Draw Project. Time has been spent in preparation for the geological portion of the presentation and the workshop. The development of the geological interpretation, integration of the seismic and reservoir data, and a discussion of the reservoir petrography and composition as it relates to log analysis and reservoir productivity will be covered. The full core from NDP Well \#23 will also be included in the presentation and workshop.

Internet Homepage: One of the pertinent technology transfer objectives was the rapid dissemination of the technology that had a direct influence on the characterization of the NDP. Towards this objective, the New Mexico Petroleum Recovery Research Center created an Internet Webpage specifically dedicated to the Nash Draw project which can be accessed at the URL (address) http://baervan.nmt.edu/prrc/resdiv/react/reactnew.html. This address 
accesses the REACT (Reservoir Evaluation and Advanced Computational Technologies) homepage. By clicking on REACT PROJECTS section, the NASH DRAW project may be accessed.

The current site is being modified to include the previous reports and the most recent annual report. The annual report will be included as a downloadable document from the NDP Internet site available at URL given above. 


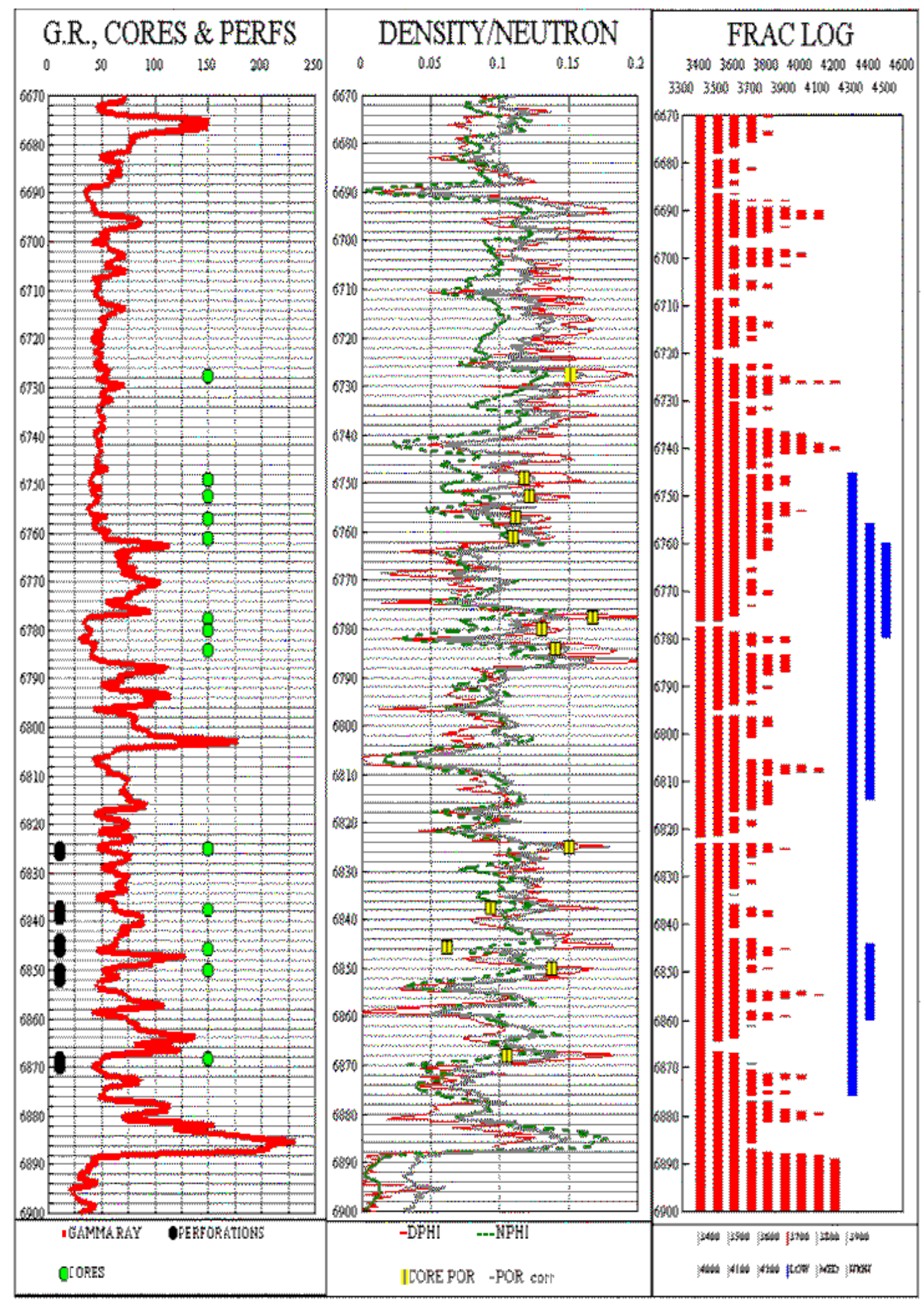

Fig. 1. Before and after frac log. 


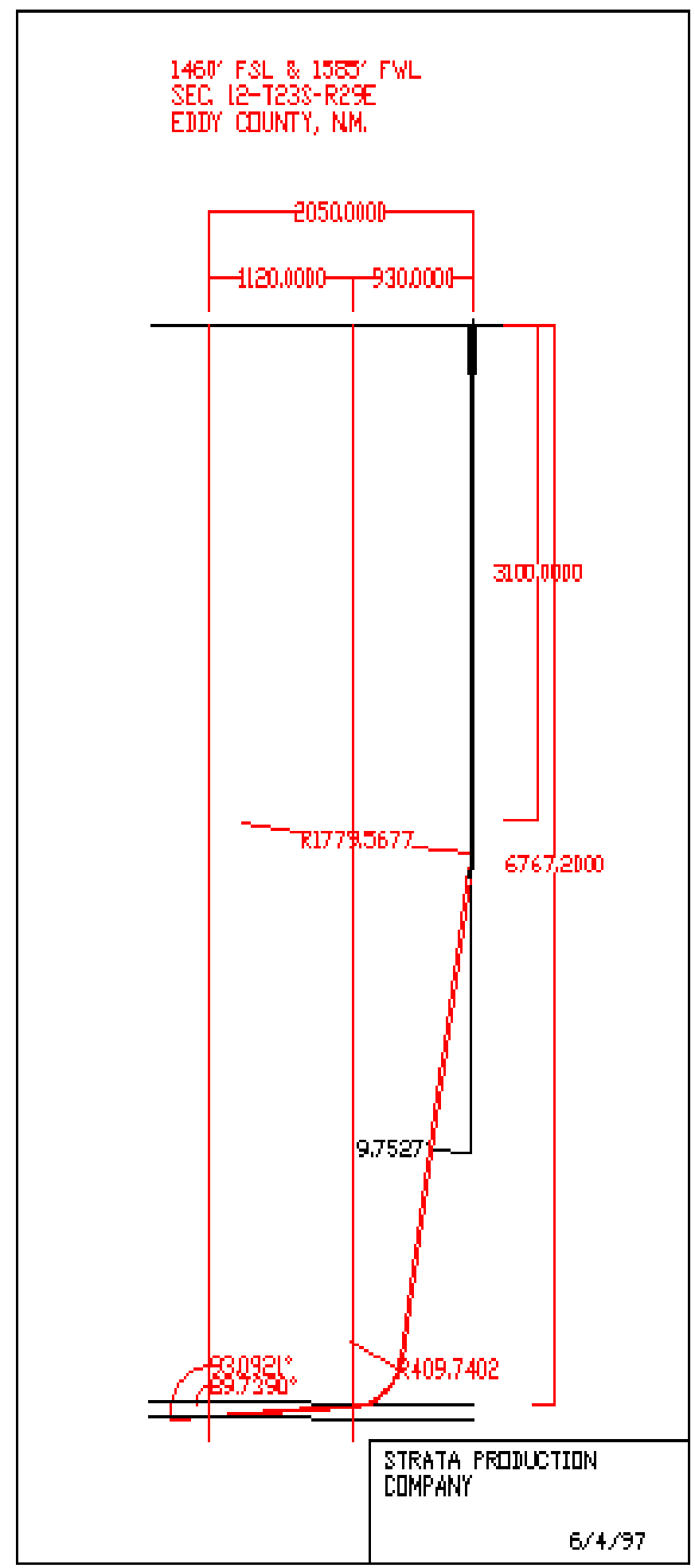

Fig. 2. Deviated-horizontal well. 


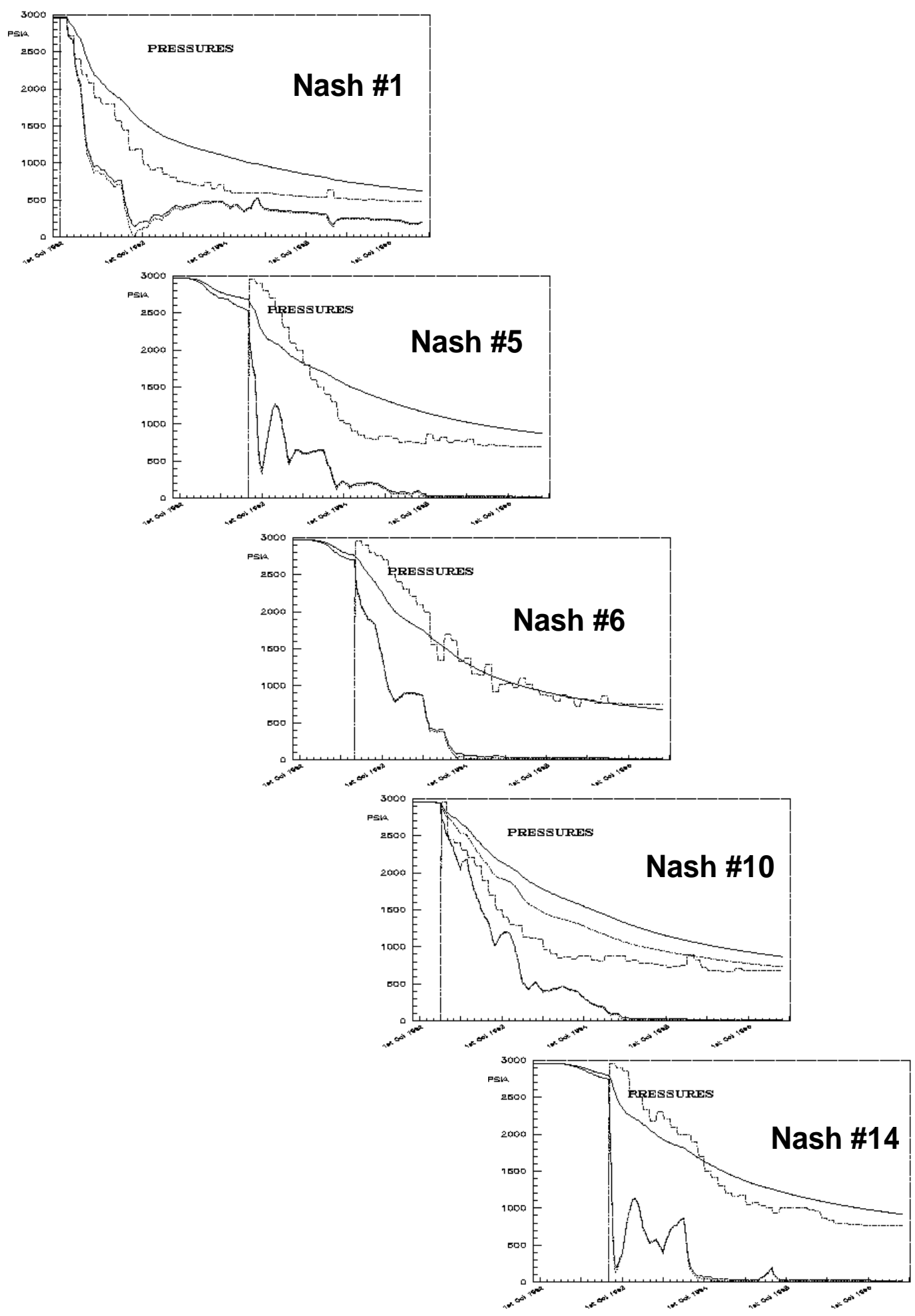

Fig. 3. Simulated pressure responses for the five pilot wells. 

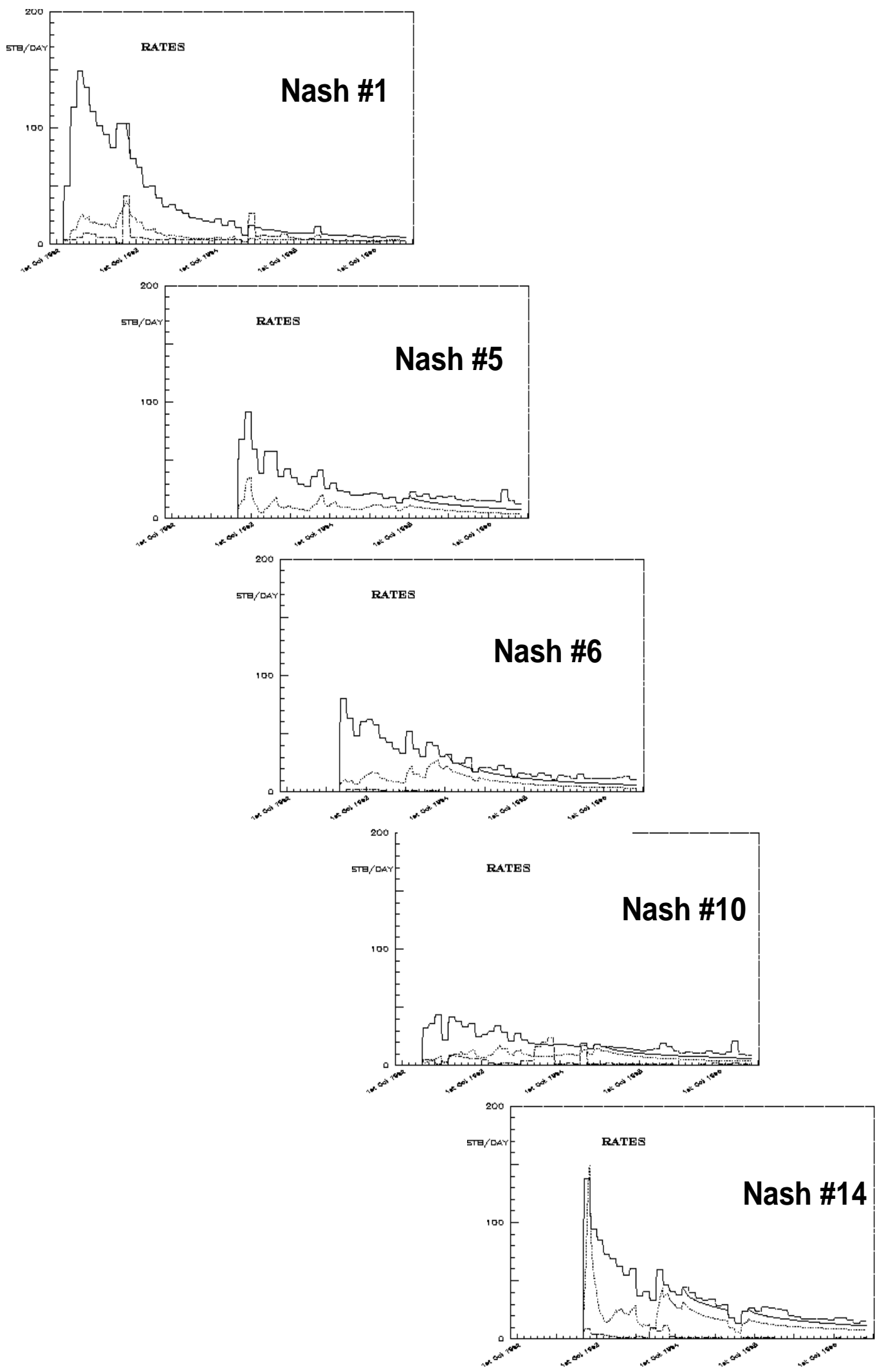

Figure 4. Oil rates for the five pilot wells. 


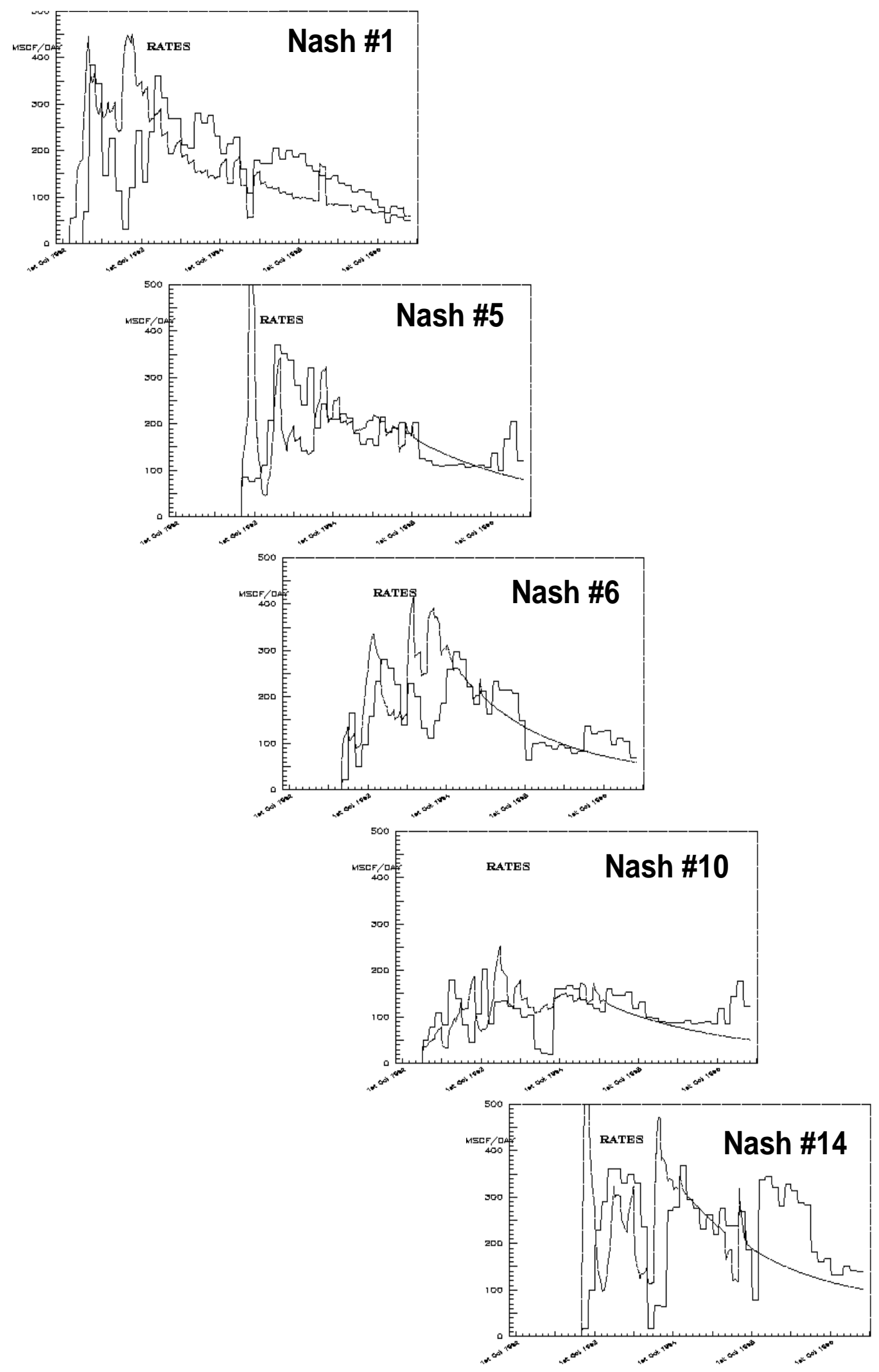

Fig. 5. Simulated and observed gas production rates for the five pilot wells. 